\title{
INSTITUTIONAL FRAMEWORK OF GOVERNMENT SUPPORT FOR UKRAINIAN FARMS
}

\begin{abstract}
Kateryna LADYCHENKO, International Trade and Law Faculty, Kyiv National University of Trade and Economic, Kioto str.23,Kyiv, Ukraine,02156, ladychenko.kateryna@gmail.com.

Anna METELSKA, Department of international economic relationship, Faculty of International Trade and Law, Kyiv National University of Trade and Economic, Kioto str.19,Kyiv, Ukraine, 02156, anna.metel18@gmail.com.

The study aimed to explore the current situation and services efficiency level of problems of Institutional framework of government support for Ukrainian farms. Nowadays, the agrarian sector of the economy shows a positive dynamics of growth, forming in recent years about $14 \%$ of gross value added in the country and about $40 \%$ of foreign exchange earnings on exports in Ukraine. This article aims to examine, through content analysis and statistical description, the importance of the agrarian sector in the national economy and its role in ensuring the country's food security requires the sustainability and effectiveness of its development based by experiences of USA and Europe practices.

Therefore, the study examined the development of farming and service cooperatives are the necessary actions of the state, aimed at ensuring that a person working on the ground can earn enough money to be interested in continuing the work on his own land.

Research data were collected from State Statistics Service of Ukraine, World Economic Forum and The European Statistical System. Research results showed that creating new jobs in the countryside are taxes to local budgets, and the development of rural areas, and the slowdown of urbanization, the reduction of the rate of extinction of the Ukrainian village. Such economic results, supplemented by the solution of other problems that farmers say, will obviously be better prepared for the opening of the land market in the future.
\end{abstract}

Keywords: governmental support, Ukrainian farms, land market, state aids, rural development.

\section{INTRODUCTION}

The current moment is determined by the rapid technological development that affects all spheres of the economy, with the simultaneous crisis of the usual economic, social, political, and cultural models. Many scholars and thinkers promise in the near future significant changes in the socio-economic structure and world order.

At the same time, Ukraine significantly slows down its modernization. Economic and political systems remain closed, with a level of economic freedom, the country ranked 76th in the Doing Business rating in 2017 (International Bank for Reconstruction and Development information, 2017). This not only limits the ability to achieve the "goals of sustainable development", defined by mankind, but also jeopardizes the very existence of Ukraine in the face of global political tension, a vivid manifestation of which was Russian aggression. The positions of Ukrainian business are subject to great pressure from political risks, military threats, financial instability, fluctuations in prices on world markets, and so on.

The agro-industrial complex is one of the key sectors of the Ukrainian economy. In 2016, the AIC produced products at UAH 277.2 billion, representing $11.63 \%$ of the GDP of the state as a whole (Table 1).

According to current situation, the main problem is how effectively use state support of agricultural sector and which effect it will show. The purpose of the study is to determine the level and directions of state support to the agrarian sector of Ukraine's economy, as well as further improvement of its forms and methods for increasing the competitiveness of agrarian sector products in the conditions of globalization and technological development.

\section{RESEARCH METHODS}

To meet the purpose, economic analysis of statistical data, synthesis and expert survey have been used.

\section{RESEARCH RESULTS}

The main directions of the state support of the agricultural sector

The share of agrarian and food products in Ukraine's exports in 2016 amounted to $42.63 \%$, which is $4.63 \%$ more than in the previous year. Implementation of agricultural products in foreign markets provides significant foreign exchange earnings in Ukraine, which has a positive impact on the country's balance of payments, contributes to improving 
the economy and strengthening the national monetary unit. Crop production is the main focus of the agroindustrial complex of Ukraine, which provides leading positions in world markets. Despite the temporary loss of a large part of the cultivated land, Ukraine is increasing its production of all major crops (Forbes Ukraine information, 2017).

Table 1.Dynamics of quota of agriculture, forestry and fishing in GDP

Table 1.Dynamics of quota of agriculture, forestry and fishing in GDP
\begin{tabular}{|r|r|r|l|r|}
\hline & & \multicolumn{2}{l}{$\begin{array}{l}\text { GVA of agriculture, forestry and fishing } \\
\text { (basic prices, mln.UAH) }\end{array}$} & quota a/c in GDP, \% \\
\hline 2012 & GDP (basic prices, mln.UAH) & GDP gain, \% & 113245 & 8.04 \\
\hline 2013 & 1408889 & 3.00 & 132354 & 9.10 \\
\hline 2014 & 1454931 & 7.70 & 161145 & 10.29 \\
\hline 2015 & 1566728 & 26.30 & 239806 & 12.11 \\
\hline 2016 & 1979458 & 20.40 & 277197 & 11.63 \\
\hline
\end{tabular}

Source: made by authors on the basis of Ministry of finance of Ukraine information (Available at: https://www.minfin.gov.ua/)

After analyzing the Statistical Yearbook "Agriculture of Ukraine" by State Statistics Service of Ukraine, it is increasing of GDP in basic prices; also, it is increasing of quota of agriculture, forestry and fishing in GDP. It shows us, that agricultural sector is one of the main part of Ukrainian GDP (State Statistics Service of Ukraine information, 2017).

The highest growth rate - twice during the last 6 years - the production of sunflower is growing: from 6772 thousand tons in 2010 to 13627 thousand tons in 2016, which provides Ukraine with the first place in the world in terms of sunflower oil production - 4.4 million tons, as well as for its exports, which last year amounted to $\$ 4.8$ billion. Ukraine is the largest producer of grain and legume crops in terms of physical terms - 66088 thousand tons in 2016. This harvest is a record in the history of Ukraine and 5.9 million tons more than in 2015 (Association of milk producers of Ukraine information, 2017).

However, even at such pace of growth, Ukraine is far from world leaders in agricultural productivity. So, the world record for wheat crop set by farmers in New Zealand is $165.19 \mathrm{c} /$ ha, while in Ukraine $-42.1 \mathrm{c} /$ ha, when average yield of wheat in EU is $61 \mathrm{c} / \mathrm{ha}$. This indicates the lack of effective use of land resources and the low level of technology development in agriculture. AIC products are one of the main components of Ukraine's exports and in 2016 amounted to $\$ 15.5$ billion and $42.63 \%$ respectively. At the same time, the largest volumes of export of agricultural products were made in 2012 - more than \$ 16 billion (State Statistics Service of Ukraine information, 2017).

According to the state fiscal service of Ukraine, the priority direction of export of Ukrainian agricultural products is Asian countries, which, according to the results of 2016, account for $45.9 \%$ of total exports of agricultural products. The export feature in 2016 is the strengthening of Ukraine's position in the Asian agribusiness markets.

Investment attractiveness of agriculture is confirmed by the figure of $49.5 \%$ growth of capital investments in January-December 2016. The importance of the agrarian sector in the national economy and its role in ensuring the country's food security requires the sustainability and effectiveness of its development.

Important factors of the long-term sustainability of the agrarian sector of the economy in terms of economic and social indicators are the economic-organizational and sectoral structure. As of today, $43 \%$ of gross agricultural production is made by citizens on land plots of a private peasant farm. As a rule, it is not export-oriented products, whose logistics are insufficient and whose production requires significant labor costs: fruit and berries - 80.9\%, potatoes - 97.8\%, vegetables $-86.1 \%$, milk $-74.9 \%$ in the overall structure of the production of the corresponding product (Association of milk producers of Ukraine information, 2017).

These figures may be possible, because various subjects are involved in the financing of the production and marketing of agricultural products (Merzlyak A., Pavelko N., 2013):

- banks in case of financing working capital needs ;

- $\quad$ suppliers of materials and equipment giving commodity loans / delayed payment for supplied materials;

- non-bank financial institutions (leasing companies, credit unions) leasing of equipment, transport, equipment and industrial real estate;

- $\quad$ value added chains using off-road transaction, subscription;

- $\quad$ agrotraders that offer forward contracts, subscription;

- $\quad$ state using subsidies, interest compensation on loans.

Ukrainian agriculture sector has opportunity to be profitable without state subsidies. We believe that in the future, those countries where the agricultural business operates without subsidies will be the most competitive.

For 2018, the budget will allocate 6.3 billion UAH for supporting agricultural sector. The main emphasis is on supporting livestock. It will be three branches such as beef cattle breeding (cattle), dairy cattle breeding and pig production. For these purposes will be allocated 2 billion UAH for 2018. For the first time, it is planned to involve the banking sector to select companies that will receive subsidies. These funds will be used to partially or fully repay the rate on loans that will be issued by commercial banks for the construction or reconstruction of livestock complexes in these industries. Thus, the risk of corruption distribution of subsidies is avoided (Verkhovna Rada of Ukraine information, 2017).

Another 300 million hryvnia will be used to improve genetics in livestock. This concerns the purchase abroad of both animals and genetic material (Verkhovna Rada of Ukraine information, 2017).

One of the main directions for supporting is farming. For this purpose government plan to use 1 billion of UAH. It is planned to do the model when a middle class appears in the countryside and the farmers will become its basis. 
This billion will be divided into two equal parts. The state will finance cooperatives that must be formed around processing and storing products, and funds will be sent directly to farmers. Family subsidies will be subsidized for the first time. Priority will be branches: vegetable growing, horticulture, niche crops, bioenergetics. It is planned to provide some small starting capital to people who first wanted to farm. In fact, starting capital in some cases you need very little. For example, in order to lay a raspberry plantation on its share in a couple of hectares, several tens of thousands of hryvnias are needed (Verkhovna Rada of Ukraine information, 2017).

Another 2 billion UAH out of 6.3 billion will be directed to the budget subsidy program. In 2018, unlike in 2017, the principle "no more than 150 million UAH per company receiving such subsidies" will operate. Therefore, even if the program funding is reduced by half, there will be enough money (Verkhovna Rada of Ukraine information, 2017).

Another 1 billion USD will be directed to partial cost recovery when buying domestic agricultural machinery with a high level of localization (Verkhovna Rada of Ukraine information, 2017).

The introduction of systemic support for farming will increase the production of gross agricultural products twice in three years - up to $12 \%$ - and develop the processing of raw materials within the country. This will ensure an increase in foreign exchange earnings from agrarian exports and increase margin for economic entities.

As a result of the implementation of the concept, it is expected to increase the share of farms in the production of gross agricultural products to $12 \%$, increase the number of jobs by five times - from 100 thousand to 0.5 million, technical re-equipment of farmers, increase by $10 \%$ of the area under organic crops.

The concept will stimulate the acquisition of farmers' status as farmers and the unification of farmers into cooperatives.

In 2016 Ukraine exported agricultural products for more than \$ 14 billion - this is $38 \%$ of the total national exports. The share of agriculture in the GDP structure last year exceeded 10\% for the first time, and the country is already one of the three largest world exporters of agricultural products. The locomotive of Ukrainian agribusiness has become large agroholdings, which handle land banks of several thousand hectares each. They, undoubtedly, are innovators in the management and implementation of new technologies. Large agricultural holdings use economies of scale and can profitably operate internationally. For example, they directly purchase so without overpayments, purchase the latest equipment, and independently make a decision on the selling prices, volumes and frequency of deliveries of their products. Also, large agrarian enterprises can attract investments in international capital markets on very favorable terms, and in times of crisis they have access to a larger list of anti-crisis tools. And all this despite the fact that the agroholdings themselves control no more than 15-20\% of Ukrainian agricultural land and produce up to $30 \%$ of all agricultural products in the country (Infoindustria, 2017).

The rest of the agricultural producers - small and medium-sized agricultural companies, private farms and farmers - provide more than $70 \%$ of all agricultural products. But despite this, small agrarians are not able to use the opportunities that are used by large agroholdings. It is for this reason that in countries with an export-oriented agricultural sector, almost all small agricultural producers become members of agricultural cooperatives.

A good example of such a cooperative approach is agriculture in the Netherlands, one of the most effective in the world. The first reason for such efficiency is modern technologies, high level of mechanization and qualitative fertilizers. The second reason is no less important - about 100,000 small family farms, more than half of which have land plots with an area of less than 10 hectares, are united in cooperatives. As a result, the high level of self-discipline and labor organization on such farms is strengthened by the developed system of agricultural cooperation in this country. For example, almost the entire flower industry of the Netherlands is the cooperative property of most of the country's floricultural farmers. Cooperatives provide farmers with the necessary equipment for growing flowers; ensure the selection of new promising varieties. More than $95 \%$ of the grown produce is sold by farmers also through their cooperatives - so you can sell flowers at the most optimal market prices (Infoindustria, 2017).

Similarly, half of all farm milk in Belgium, the UK and Poland is sold through a cooperative system that belongs directly to farmers. In the Netherlands, Austria and Denmark, this share exceeds 95\%. In the European Union and North America, almost $90 \%$ of dairies are cooperative (Filippi, M., R. Kühl, B. Smit, 2016).

In Spain and Greece, over $60 \%$ of farm olive oil is sold through cooperatives, in Finland - $70 \%$ of meat, in Belgium - 70\% of fruits and vegetables. And, finally, more than half of the grain harvested by French and Austrian farmers is stored on co-operative elevators belonging not to traders, but directly to agricultural producers themselves (Soboh R, 2016).

The experience of the advanced countries shows that with the help of cooperatives it is possible to reduce the number of intermediaries in the process of promoting products from the producer to the end user. Serving cooperatives in these countries is one of the main forms of self-organization and self-help of agricultural producers. And there are two main types of agricultural serving cooperatives: procurement and marketing (or marketing). Procurement cooperatives supply their members with the necessary materials for agricultural production: seeds, fertilizers, fuel, machinery, etc. Marketing cooperatives are created by farmers for processing, packaging and marketing of agricultural products.

Members of the cooperative own capital, trust the cooperative with their harvest, assign it a development mission, carry out marketing and start selling their products. At the same time, the cooperative allows farmers to continue making decisions at the micro level, that is, to take into account the specifics of their land and agricultural crops, which the agricultural holding cannot afford. The cooperative allows farmers to work for export without intermediaries, as large holdings do. The attraction of loans, financing, as well as the opportunity to modernize the activities are additional advantages of the cooperative. Also, the cooperative does not require an initial substantial infusion of funds (Onys'ko S., Kits M, 2014).

According to the State Statistics Service (from November 1, 2016), the number of active farms is 33,682 units. They process 4,439 million hectares of land. About $80 \%$ of farms cultivate land with an area of up to 500 hectares (State Statistics Service of Ukraine information, 2017). 
The largest number of farms is located in Zaporozhye, Odesa, Mykolayiv, Dnipropetrovsk, Kherson and Kirovograd regions. And the smallest is in Rivne, Ivano-Frankivsk, Chernivtsi and Chernihiv regions. Unfortunately, many of them really are not such, as they actually only lease the land to agricultural holdings. The effectiveness of a large number of such cooperatives remains questionable.

Nevertheless, there are 4 reasons according to which government's supporting must be.

First of all, we give off growth of production costs of agricultural producers. The increase of the minimum wage twice (up to $3200 \mathrm{UAH}$ at the beginning of this year) has forced enterprises to increase tax deductions and wages, while the rise in energy and fuel and lubricants automatically increased other expenses. According to the State Statistics Service, the price index for January-September for material and technical resources of industrial origin, consumed by agriculture increased by $26.7 \%$ compared to the same period last year. All these factors in the complex led to an increase in the cost of livestock production in January-September by $18.8 \%$ (State Statistics Service of Ukraine information, 2017).

Secondly, we pay attention on positive effect of dotation. Despite the increase in the production costs of agricultural producers and a number of shortcomings, the budget agrarian subsidy gave the first positive results for livestock production. For the first time in the last five years, the production of milk, eggs and sales for slaughter of cattle and poultry in live weight did not decrease in relation to the same previous period. With some reservations, the new mechanism of state support through the "quasi-accumulation of VAT", which in fact was the only state subsidy to the farmers, played a role in this process. Other state support programs were not actually implemented at this time.

By the end, these actions will decrease corruption risks. The government reduces the volume of state subsidies to compensate for the increase in financial support for the development of farms and rural cooperatives; partial compensation of the cost of purchased agricultural machinery and equipment of Ukrainian production; support of the livestock sector, in particular, in the areas of construction and reconstruction of livestock complexes.

Certainly, such support is necessary, but previously such programs have never been executed completely or not performed at all. Despite such statistics, next year it is planned to increase dozens of times in subsidies for articles that, in our opinion, are mainly populist. After all, in fact, no analytical work was carried out.

Last one is supporting of young Ukrainians farmers. More recently, more and more young, ambitious farmers are entering the agrarian sector, who want to change the future of the industry for the better. These are, as a rule, former top managers, lawyers and economists who, having accumulated experience in other fields, bring him to agriculture, open their own small and medium farms. Such small and medium-sized farmers have the opportunity to grow and produce for consumers an exclusive, environmentally friendly product that has become more and more popular in recent times. For that government needs to:

- implement regional planning of crops and production in rural communities in order to avoid depreciation or shortage of goods.

- create associations of farmers in small cooperatives that will produce the same type of products.

- provide loans from state-owned banks with a seasonal repayment for the purchase of Ukrainian tractors 25 horsepower with trailer equipment.

- start a social advertisement with appeals to buy a Ukrainian product.

\section{CONCLUSIONS AND DISCUSSION}

According to our assessment, Ukraine can expect:

- to increase the number of farms having cultivation, ownership and use of land with a total area of no more than 100 ha by $10 \%$;

- $\quad$ to increase in the share of farms in the production of gross agricultural products to $12 \%$;

- to increase the number of agricultural servicing cooperatives founded by farmers on their own or in association with members of private peasant farms for 40-50 units;

- to increase in the area of agricultural land where $10 \%$ of organic produce is produced and / or produced;

- the creation of 15 new primary agricultural products per year;

- to stop the reduction in the number of cattle in farms and increasing it by $2.5 \%$;

- to increase in the share of livestock production by farms in the structure of gross production to $3 \%$;

- $\quad$ to increase in the area of perennial plantations in farms by $15 \%$;

- to increase the level of energy supply of farms by $10 \%$.

The research reflects the results of studies of authors within the scientific research works carried out in 2017 at Kyiv National University of Trade and Economics for the Ministry of Education and Science of Ukraine ("Strategic partnership in terms of economic security of Ukraine" state registration 0116U000785; "Formation of the Ukraine national brand in the international environment").

\section{REFERENCES}

1. Association of milk producers. 2017. Agriculture in Ukraine sets the record for profitability. Available at http://avmua.org/uk/post/silske-gospodarstvo-v-ukraini-vstanovlue-rekordi-rentabelnosti?milkua=1 (Accessed on 13/11/2017)

2. Filippi, M. R. Kühl, and B. Smit. 2016. Support for Farmers' Cooperatives. Case Study Report: Cosun, Südzucker/Agrana, Tereos and differences in internationalisation of sugar cooperatives. 
3. Forbes Ukraine. 2017. Prospects-2017: what to expect in Ukrainian agroindustrial complex in the new year. Available at http://forbes.net.ua/ua/opinions/1426443-perspektivi-2017-chogo-chekati-ukrayinskomu-apk-v-novomu-roci (Accessed on 12/11/2017)

4. Infoindustria. 2017. The EU will allocate EUR 95.6 billion to rural development for 2014-2020. Available at http://infoindustria.com.ua/yes-protyagom-2014-2020-rokiv-vidilit-na-silskiy-rozvitok-95-6-mlrd-yevro-a-ukrayina/ (Accessed on $12 / 11 / 2017$ )

5. International Bank for Reconstruction and Development / The World Bank. 2017. Doing Business 2017. Available at http://www.doingbusiness.org/ /media/WBG/DoingBusiness/Documents/Annual-Reports/English/DB17-Report.pdf (Accessed on 10/11/2017)

6. Merzlyak A., Pavelko N. 2013. Role of government support in the development of insurance agricultural products in Ukraine. Derzhava ta Rehiony. Vol.1, pp. 88-94 [In Ukraine].

7. Ministry of finance. 2017. Gross Domestic Product. Available at http://index.minfin.com.ua/index/gdp/?2016 (Accessed on 13/11/2017)

8. Soboh, R., Oude Lansink, A. \& Van Dijk, G.2016. Efficiency of Cooperatives and Investor Owned Firms. Journal of Agricultural Economics, Vol. 63, pp. 142-157

9. Onys'ko S., Kits M. 2014. Conceptual principles of forming of the effective system of state support of agricultural entities. Ahrarna ekonomika, Vol. 7, Iss. 1, pp. 7-11.

10. State Statistics Service of Ukraine. 2017. The Statistical Yearbook "Agriculture of Ukraine" for 2016. Available at http://agroua.net/statistics/ (Accessed on 14/11/2017)

11. Verkhovna Rada of Ukraine. 2017. Draft Law on the State Budget of Ukraine for 2018. Available at http://w1.c1.rada.gov.ua/pls/zweb2/webproc4_1?pf3511=62551 (Accessed on 14/11/2017) 